\title{
Citizenship, Justice and the Right to the Smart City
}

\author{
Rob Kitchin ${ }^{1}$, Paolo Cardullo² and Cesare Di Feliciantonio ${ }^{3}$
}

1. Rob Kitchin, Maynooth University Social Sciences Institute and Department of Geography, Maynooth University. Rob.Kitchin@mu.ie

2. Paolo Cardullo, Innovation Value Institute, Maynooth University, Paolo.Cardullo@mu.ie

3. Cesare Di Feliciantonio, School of Geography, Geology and the Environment, University of Leicester, difeliciantoniocesare@gmail.com

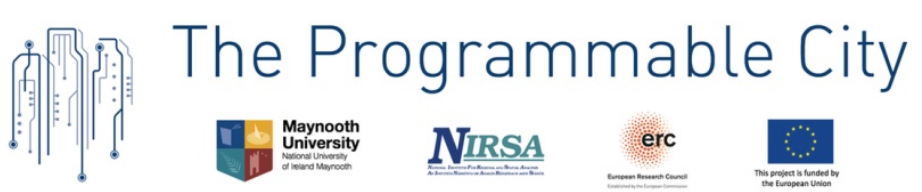

The Programmable City Working Paper 41

http://progcity.maynoothuniversity.ie/

18 October 2018

Published as an open access pre-print on SocArXiv: https://osf.io/preprints/socarxiv/b8aq5

This is a modified, pre-print version of the opening chapter in the book 'The Right to the Smart City' edited by Paolo Cardullo, Cesare Di Feliciantonio and Rob Kitchin to be published by Emerald Publishing.

\begin{abstract}
This paper provides an introduction to the smart city and engages with its idea and ideals from a critical social science perspective. After setting out in brief the emergence of smart cities and current key debates, we note a number of practical, political and normative questions relating to citizenship, justice, and the public good that warrant examination. The remainder of the paper provides an initial framing for engaging with these questions. The first section details the dominant neoliberal conception and enactment of smart cities and how this works to promote the interests of capital and state power and reshape governmentality. We then detail some of the ethical issues associated with smart city technologies and initiatives. Having set out some of the more troubling aspects of how social relations are produced within smart cities, we then examine how citizens and citizenship have been conceived and operationalised in the smart city to date. We then follow this with a discussion of social justice and the smart city. In the final section, we explore the notion of the 'right to the smart city' and how this might be used to recast the smart city in emancipatory and empowering ways.
\end{abstract}

Keywords: citizenship, social justice, smart cities, right to the city, ethics 


\section{Introduction}

Since the 1950s and the birth of digital computing, the urban has become ever-more entwined with the digital. Initially, computers were used to store and process city administration, were enrolled into SCADA (Supervisory Control and Data Acquisition) systems to monitor and control utility and other infrastructures, and used within academia and policy for modelling land use and transportation scenarios. By the late 1960s, cybernetic thinking led some to recast the city as a system of systems which could be digitally mediated and optimized (Forrester, 1969), though early deployments of such ideas failed to deliver on their promise (Flood, 2011; Light, 2004). In the 1980s and 1990s, personal computers began to become widespread in central and local government, along with specialist software (e.g. GIS), used in administration and the delivery of services. These computers started to become increasingly networked with the rapid growth of the internet in the 1990s and 2000s, which was accompanied by a large investments in e-government (the delivery of services and interfacing with the public via digital channels) and e-governance (managing citizen activity using digital tools) (Castells, 1996). This also extended the networking of infrastructure, such as the widescale adoption of traffic management systems and surveillance cameras (e.g., CCTV) (Lyon, 1994).

By the late 1990s, there was a fairly extensive literature that examined the myriad ways in which the digital was reshaping the politics, economy, culture, social relations, and functioning of cities (e.g., Castells, 1988, 1996; Graham \& Marvin, 2001; Mitchell, 1995; „, 2001), with theses emerging with regards to 'wired cities' (Dutton et al., 1987), the 'city as bits' (Mitchell, 1995), the 'computable city’ (Batty, 1997), and 'cyber cities’ (Graham \& Marvin, 1999). As the entwining of the digital and urban deepened throughout the 2000s with the emergence of ubiquitous computing and mobile ICT, these were accompanied by conceptual framings such as 'digital cities’ (Ishida \& Isbister, 2000), 'intelligent cities’ (Komninos, 2002), 'networked cities’ (Hanley, 2004), and 'sentient cities’ (Shepard, 2011), among others (Kitchin, 2014; Willis \& Aurigi, 2017).

The smart city agenda is grounded in and emerges from this longer history of urban computing and networked urbanism. In simple terms, the smart city seeks to improve city life through the application of digital technologies to the management and delivery of city services and infrastructures and solving urban issues (see Table 1). Unlike other neologisms, the 'smart city' quickly gained traction in industry, government and academia from the late 
2000s onwards to become a global urban agenda (see Sőderstrőm et al., 2014; Willis and Aurigi, 2017). In part, this traction was driven by companies rapidly seeking new markets for their technologies in the wake of the global financial crash, and in part, by city administrations simultaneously seeking ways to do more with less through technical solutions given austerity cuts, and to attract investment and boost local economies. This was aided by an already well-established neoliberal political economy that promoted the marketisation and privatisation of city services. Initial momentum grew, aided by the rapid formation of a wellorganized epistemic community (a knowledge and policy community) and advocacy coalition (a collective of vested interests) operating across scales from global to local, and a cohort of favourably-minded technocrats embedded in government (Kitchin et al., 2017a).

Table 1: Smart city technologies

\begin{tabular}{|l|l|}
\hline Domain & Example technologies \\
\hline Government & $\begin{array}{l}\text { E-government systems; online transactions; city operating systems; } \\
\text { performance management systems; urban dashboards }\end{array}$ \\
\hline Security and emergency services & $\begin{array}{l}\text { Centralised control rooms; digital surveillance; predictive policing; } \\
\text { coordinated emergency response }\end{array}$ \\
\hline Transport & $\begin{array}{l}\text { Intelligent transport systems; integrated ticketing; smart travel cards; } \\
\text { bikeshare; real-time passenger information; smart parking; logistics } \\
\text { management; transport apps; dynamic road signs; mobility apps; } \\
\text { share-ride services }\end{array}$ \\
\hline Energy & Smart grids; smart meters; energy usage apps; smart lighting \\
\hline Waste & Compactor bins and dynamic routing/collection \\
\hline Environment & $\begin{array}{l}\text { loT sensor networks (e.g., pollution, noise, weather; land movement; } \\
\text { flood management); dynamically responsive interventions (e.g., } \\
\text { automated flood defenses) }\end{array}$ \\
\hline Buildings & Building management systems; sensor networks \\
\hline Homes & $\begin{array}{l}\text { Smart meters; app-controlled smart appliances; digital personal } \\
\text { assistants }\end{array}$ \\
\hline
\end{tabular}

Source: Kitchin (2016)

From its inception the notion of the smart city has received sustained critique relating to how it: frames the city as systems rather than places; takes a technological solutionist approach; enacts technocratic forms of governance and reshapes governmentality; promotes corporatisation and privatisation of city services; prioritises the values and investments of vested interests; reinforces inequalities; produces a number of ethical concerns relating to surveillance, predictive profiling, social sorting and behavioural nudging; and potentially creates security vulnerabilities across critical infrastructures (see Datta, 2015; Greenfield, 
2013; Hollands, 2008; Kitchin, 2014; Mattern, 2013; Townsend, 2013; Vanolo, 2014). In this book, we are particularly concerned with critique relating to issues of citizenship, social justice and the 'right to the city' and the ways in which ordinary citizens lives are affected by the drive to create smart cities.

Our concern is not to forward a line of argument that is simply 'against the smart city'; after all, digital technologies are already extensively interwoven into the workings and everyday life of cities and produce many positive and enjoyable effects. Indeed, such technologies are, in Althusser's (1971) terms, 'seductive', promising freedom and choice, convenience, productivity, optimisation, and control (Kitchin \& Dodge, 2011). However, seduction can be a veil, obfuscating the broader agenda and processes of neoliberalization and accumulation by dispossession that may disadvantage citizens in the long run (Leszczynski \& Kitchin, in press). Instead, we seek to "reframe, reimagine and remake the smart city” (Kitchin 2019, p. 219) as an emancipatory and empowering project; one that works for the benefit of all citizens and not just selected populations.

This re-conception consists of highlighting further the politics and ethics of smart cities, and to move beyond the dominant post-political framing reproduced by its epistemic community and advocacy coalition; to reconceive notions of 'smart' citizenship and the purposes and ideology of smart city endeavours in ways that are thoroughly political. This means not simply stating the need for citizen-focused or just smart cities at the level of the commonsensical, taken-for-granted, pragmatic and practical, but to conceptualize what such notions consist of in concrete terms and how they can be operationalized to transform the smart city. This involves starting to work through a set of related questions, such as:

- How are citizens framed and conceptualized within smart cities?

- How are citizens expected to act and participate in the smart city?

- How is public space and the urban commons framed and regulated in the smart city?

- What sort of publics can be formed and what actions can they take?

- What are the ethical implications of smart city approaches and systems?

- To what extent are injustices embedded in city systems, infrastructures and services and in their calculative practices?

- What systems and structures of inequality are (re)produced within smart urbanism?

- To what extent are forms of class, racism, patriarchy, heteronormativity, ableism, 
ageism, colonialism (re)produced in smart urbanism?

- What models of citizenship are enacted within the smart city?

- What forms of social justice operate in the smart city and what are their effects?

- By whom and on what terms are these models of citizenship and justice being conceived and operationalised?

- What kind of smart urbanism do we want to enact? What kind of smart city do we want to create and live in?

- How can we move beyond the neoliberal smart city?

In the rest of this paper we provide a framing for starting to think through and answer some of these questions drawing on the emerging. We have divided our discussion into five sections. In the next section we detail the dominant neoliberal framing and enactment of smart cities and how this works to promote the interests of capital and state power and reshape governmentality. We then detail some of the more troubling ethical issues associated with smart city technologies and initiatives. In the third section we examine how citizens and citizenship have been conceived and operationalised in the smart city to date, following this with a discussion of social justice and the smart city. In the final section we set out the notion of a 'right to the smart city', making a case that this should be a fundamental principle of smart city endeavours.

\section{Capital, Power and the Smart City}

There is a plethora of work that has theorised and empirically excavated the ways in which capital and power drive the processes of urbanization and reproduce socio-spatial structures and relations of cities. Such work focuses attention on the circuits of capital accumulation, the operations of neoliberalism, imperialism, colonialism and nationalism, and the playing out of identity politics in shaping the urban condition across the globe (e.g., Castells, 1977; Harvey, 1973; Massey, 2007; Robinson, 2005). Cities, critical urban theory posits, "are sculpted and continually reorganized in order to enhance the profit-making capacities of capital" since they are "major basing points for the production, circulation, and consumption of commodities," as well as themselves being intensely commodified (Brenner et al., 2012, p. 3). This continual unfolding shifts in shape and emphasis through the clash of vested interests, social forces, and political ideologies, and is subject to instability, multiple setbacks 
and crises (e.g., overaccumulation, devalorization), but relentlessly prioritises exchange-value (profit-oriented) over use-value (the satisfaction of basic needs) in urban development strategies (Lefebvre, 1996; Brenner et al., 2012). In other words, cities under capitalism operate for the benefit of a relatively small group of elite actors who own and control the means of production, and reproduce inequalities and social and spatial divides (Harvey, 1973; Sassen, 1991).

From this perspective, the smart city is the latest attempt to use and reconfigure the city as an accumulation strategy, forming a tech-led version of entrepreneurial urbanism (Hollands, 2008; Shelton et al., 2015), through which private interests seek to: deepen a neoliberal political economy, capturing public assets and services by offering technological solutions to urban problems; use financialisation to capture and sweat or disrupt and replace private infrastructure and services; foster local economic development and attract foreign direct investment; drive real-estate investment; and set in place the architecture of neoliberal governmentality and governance. Through these strategies the smart city enacts a new wave of ‘accumulation by dispossession’ (Harvey, 2008) and 'capitalist enclosure’ (De Angelis, 2007) that have significant consequences to the lives of citizens.

With respect to capturing public assets, city administrations are under pressure to draw on the competencies held within industry to formulate 'smart' urban policy and to deliver tech-led city services through public-private partnerships, leasing, deregulation and market competition, and privatization (Shelton et al., 2015). Cities, it is argued, are behind the technology-curve with respect to state-of-the-art ideas and systems for managing cities. They lack the core skills, knowledges, resources and capacities to address pressing urban issues and maintain critical services and infrastructures, which are becoming more socially and technically complex and require multi-tiered specialist interventions (Kitchin et al., 2017a). Within this mindset, the place of the public sector is to act as broker, rather than service provider, with smart city units acting to source initial expertise and build partnerships. At the same time, companies seek to: capture private infrastructures and services and sweat these assets, seeking to extract value through minimizing maintenance and long-term investment and charging the highest bearable price depending on a user's ability to pay (Morozov \& Bria, 2018); or to disrupt existing public and private services and infrastructures, and their regulation and labour relations, by providing new tech-enabled platforms - for example, Uber and Airbnb challenging traditional taxi and short-term accommodation 
markets. In both cases, smart city endeavours are part of a larger project of city assets (e.g., property, infrastructure, utilities, services) being captured and exploited through financialisation (Christophers, 2011; Moreno, 2014).

Beyond making the city a market in-and-of itself, the neoliberal smart city is an explicitly economic project, aiming to attract foreign direct investment, fostering innovative indigenous start-up sectors or digital hubs, and attracting mobile creative elites. Cities around the world have created 'smart districts', designating an area of the city as a testbed for companies to pilot new technologies (Evans et al., 2016; Halpern et al., 2014). In the UK, the Department of Business, Innovation and Skills has funded smart city initiatives with the aim of positioning the UK as a leading exporter of smart city consultancy and technologies (Taylor-Buck \& While, 2017). At the European scale, the European Innovation Partnership for Smart Cities and Communities (EIP-SCC) funds smart city projects where a key measure of impact is the attraction of significant private investment in the delivery of public services and a reduction in "technical and financial risks in order to give confidence to investors for investing in large scale replication” (European Commission, 2016, p. 111), so that eventually "private capital can take over further investments at low technical and financial risks" (ibid, p. 108). In other words, the risks of creating new products are socialised in exchange for the privatisation of services and, eventually, profits.

In addition to urban-focused economic development, the smart city has become a key component of property-led development. Here, smart city technologies are a central feature of new real-estate projects, operating as an attractor for investors and future residents, as well as providing a shopfront for those technologies for other prospective development sites. Probably the most well-known such development is Songdo in South Korea. A part of the Incheon Free Economic Zone (IFEZ) at the edge of the Seoul metropolitan area, Songdo is one of three large-scale developments initiated in 2003. The IFEZ was explicitly an economic development initiative aimed at driving domestic growth and consolidating South Korea's position in the global economy. From this perspective, the greenfield smart city was a means to create an urban growth machine designed to attract investment capital, anchor tenants, and global workers, with a side benefit of creating a potential exportable model of 'smart' development (Carvalho, 2012; Shin et al., 2015; Shwayri, 2013). Other examples include the 100 smart city developments in India (see Datta, 2015), Masdar in United Arab Emirates (Cugurullo, 2013), and Hudson Yards in New York (Mattern, 2017) (also see Karvonen et 
al., 2018; Di Feliciantonio, in press). In areas where smart city practices are used in regeneration programmes, such as Living Labs, they act as a magnet for the in-flow and retention of 'creative classes' and as gateways for gentrification (Cardullo et al., 2018).

Within such new smart city developments, and through the deployment of smart city technologies across existing cities, the modes of governmentality and governance are shifting, further deepening the neoliberal project. For Foucault (1991), governmentality is the logics, rationalities and techniques that render societies governable and enable government and other agencies to enact governance. For many analysts, the digital era of ubiquitous computing, big data and machine learning is producing a shift in how societies are managed and controlled. The contention is that governance is becoming more technocratic, algorithmic, automated, and predictive in nature (Amoore, 2013; Kitchin \& Dodge, 2011,), shifting governmentality from disciplinary forms of management (designed to corral and punish transgressors and instil particular habits, dispositions, expectations, and selfdisciplining) towards social control, in which their behaviour is explicitly or implicitly steered or nudged. Governmentality is no longer principally about subjectification (molding subjects and restricting action) but also about control (modulating affects, desires and opinions, and inducing action within prescribed comportments) (Braun, 2014). Vanolo (2014) names this as "smartmentality", enacted through technologies such as control rooms and dashboards, smart grids and meters, traffic control rooms, and smartphone apps that seek to modulate behaviour and produce neoliberal subjects (Kitchin et al., 2017b). For example, as Davies (2015) notes with respect to Hudson Yards, a development that will be saturated with sensors and embedded computation, residents and workers will be continually monitored and modulated across the entire complex by an amalgam of interlinked systems. The result will be a quantified community with numerous overlapping calculative regimes designed to produce a certain type of social and moral arrangement, rather than people being regulated into conformity.

\section{Ethics and the Smart City}

The technologies detailed in Table 1 are designed to manage and control city infrastructure and services. As noted above, almost without exception they are operated either on behalf of the state or for the generation of profit and they directly affect the management and regulation of society. A key aspect of their operation is that they produce, process, and extract 
value and act upon streams of big data that are highly granular and indexical (directly linked to people, households, objects, territories, transactions) (Kitchin, 2014). Thus, smart city technologies raise a number of ethical issues concerning privacy, datafication, dataveillance and geosurveillance, profiling, social sorting, anticipatory governance, and nudging, that have significant consequence for how citizens are conceived and treated (e.g., as data points; subjects to be actively managed and policed; as consumers), and can work to reproduce and reinforce inequalities (Kitchin, 2016; Taylor et al., 2016).

For example, a range of smart technologies have transformed geo-location tracking, eroding movement privacy (Kitchin, 2016; Leszczynski, 2017). Many cities are saturated with remote controllable digital CCTV cameras that can track individual pedestrians, increasingly aided by facial and gait recognition software. Large parts of the road network are monitored by inductive loops, traffic cameras, and automatic number plate recognition cameras that can identify vehicles. In a number of cities, sensor networks have been deployed across street infrastructure such as bins and lampposts to capture and track phone identifiers such as MAC addresses. The same technology is also used within malls and shops to track shoppers, sometimes linking with CCTV to capture basic demographic information such as age and gender. Similarly, some cities have installed a public wifi mesh which can capture and track the IDs of devices that access the network. Many buildings and public transport systems monitor smart cards used to access them. Smartphones continuously communicate their location to telecommunications providers, either through the cell masts they connect to, or the sending of GPS coordinates, or their connections to wifi hotspots. Such data gathering has profound implications for privacy, which many consider a basic human right.

In addition, smart city technologies potentially create a number of other privacy harms through the sharing and analysis of data trails (Kitchin, 2016). A key product of data brokers are predictive profiles of individuals as to their likely tastes and what goods and services they are likely to buy, their likely value or worth to a business, and their credit risk and how likely they are to pay a certain price or be able to meet re-payments. Such profiles can produce 'predictive privacy harms' (Baracos \& Nissenbaum, 2014; Crawford \& Schultz, 2014), used to socially sort and redline populations, selecting out certain categories to receive a preferential status and marginalising and excluding others. In addition, such profiles can be used to socially sort places to receive certain policy interventions or marketing as practised by the geodemographics industry (Graham, 2005). Specific predictive privacy harms can be 
produced through location tracking. For example, tracking data that reveal a person regularly frequents gay bars might lead to the inference that the person is likely to be gay which, if shared (e.g., through advertising sent to the family home or via social media), could cause personal harm. Similarly, co-proximity and co-movement with others might be used to infer political, social, and/or religious affiliation, potentially revealing membership of particular groups (Leszczynski, 2017). Such inferences can generate inaccurate characterization that then stick to and precede an individual. This has led to concerns that a form of 'data determinism' is emerging in which individuals are not simply profiled, judged and treated on the basis of what they have done, but on a prediction of what they might do in the future (Ramirez, 2013).

Data determinism is most clearly expressed in forms of anticipatory governance, such as that used in predictive policing, where predictive analytics are used to assess likely future behaviours or events and to direct appropriate action (Goodman, 2015; Harcourt, 2006). A number of US police forces are now using predictive analytics to anticipate the location of future crimes and to direct police officers to increase patrols in those areas. For example, the Chicago police force use arrest records, phone records, social media and other data to produce both general area profiling to identify hotspots and guide patrols, and more specific profiling that identifies individuals within those hotspots (Jefferson, 2018). In such cases, a person's data shadow does more than following them; it precedes them. Further, a number of police forces have invested heavily in new 'smart' command-and-control centres that employ enhanced and extensive multi-instrumented surveillance (e.g., high definition CCTV, drone cameras, sensors, community reporting) to direct on-the-ground policing (Wiig, 2017). In addition, police forces monitor the communications of known activists to try and anticipate and control social unrest (Paasche, 2013). In other words, smart technologies can be used to suppress dissent and reproduce a particular polity.

Smart city technologies, the data they generate and the analytics applied to them, can thus have significant negative direct and in-direct impact on peoples' everyday lives (Kitchin, 2016). They also ensure that any 'right to the smart city' derived through the present configuration of technologies is dependent on systems that inherently surveil and control. As such, there is a potentially heavy cost for the freedom and choices these technologies claim to offer, which requires careful consideration and redress. 


\section{Citizenship and the Smart City}

The discussion so far regarding power, capital, governmentality and ethics reveals the dominant ways in which the citizen is framed within the smart city: as a data-point, a targeted consumer, a user, an investor, a sorted individual, and a surveilled, controlled and policed subject. In a previous paper, we reworked Arnstein’s (1969) well-known 'ladder of citizen participation' to examine the various citizen roles enacted across smart city initiatives (see Cardullo \& Kitchin, 2018a). What we found was citizens most often occupy nonparticipatory, consumer or tokenistic positions and are framed within political discourses of stewardship, technocracy, paternalism and the market, rather than being active, engaged participants where smart city initiatives are conceived in terms of rights, citizenship, the public good, and the urban commons. Citizens are to be steered, nudged, controlled; they can browse, consume, and act. If there is civic engagement it is in the form of a participant, tester or player who provides feedback or suggestions, rather than being a proposer, co-creator, decision-maker or leader.

Similarly, Cowley et al. (2018) identify four modalities of 'publicness' which denote how citizens are positioned within smart cities: 'service user' in which citizens are framed as the consumers of services; 'entrepreneurial' in which citizens are actively enrolled into cocreating and innovating; 'political' in which citizens take an active role in decision-making and deliberation; and 'civic' in which citizens take part in grassroots community activities that are not directly oriented towards market activity. They note that there is a significant variation of publicness across initiatives and cities, mostly favouring 'service user'. In contrast, Shelton and Lodato's (in press) study of Atlanta's smart city programme notes that while the city administration and companies attending their events often talked of producing a citizen-focused smart city, in practice citizens were included as two empty signifiers - and citizens themselves were excluded from the policy-making arena (see also Datta, 2018). The first is as a 'general citizen'; a kind of catch-all community of seemingly homogenous recipients or consumers of services. Here, the smart city operates within the framework of stewardship (delivering on behalf of citizens) and civic paternalism (deciding what's best for citizens), rather than citizens being meaningfully involved in the vision and development of the smart city. The second is the 'absent citizen', referring to all those diverse communities that hold differing identities, values, concerns and experiences to the 'general citizen' (which is largely framed as white, male, heterosexual, ablebodied and middle class), and to the 
absence of citizens from the processes of formulating and implementing smart city strategies and programmes. To this can be added a third figure, that appears often in other smart city documents and programmes, the 'active citizen'; an entrepreneurial citizen that builds civic tech for community development through hackathons and other events (Joss et al., 2017; Townsend, 2013), though within any city this is usually just part of a handful of people who work in the tech sector and on problems set by sponsoring companies and administrations (Perng et al., 2018).

And yet, most smart city initiatives claim to be 'citizen-focused' or 'citizen-centric'. The disconnect between supposed discursive intent and reality is caused by two factors. First, initiatives that were critiqued for their top-down, technocratic nature have sought to silence detractors or bring them into the fold, while keeping the central mission of capital accumulation and technocratic governance intact, by re-branding their endeavours as 'citizencentric’ (Kitchin, 2015). Citizen-centric in such cases operates largely as an empty signifier, often calling for citizen inclusion or searching for the 'missing citizen' but retaining the underlying neoliberal ethos and mode of governmentality (Hill, 2013; Sartori, 2015; Shelton \& Lodato, in press). Second, funding programmes designed to encourage city administrations to become a smart city, such as the European Commission's EIP-SCC, structurally preclude any serious intent to include citizens in the formulation of projects (Cardullo \& Kitchin, 2018b). Putting together a large, multimillion euro bid is time-consuming, complex and largely unfunded task, and adding 'non-expert' citizens into the process creates a significant additional overhead. What this means is that in most cases the focus, objectives and solutions are set before any problems and suggestions from citizens can be taken into account, and it is only when the funding is in hand that engagement occurs with local communities. Such citizen engagement has to meet pre-determined milestones and fulfil the deliverables of the contract, meaning participants have limited scope to subsequently reframe the initiative around their concerns and desires (Cardullo \& Kitchin, 2018b).

This discussion of citizen roles and framing starts to reveal the dominant neoliberal model of citizenship that underpins and operates within the smart city. In his classic text, Citizenship and Social Class (1950), Marshall denoted three sets of rights that define the citizenship status of citizens: civil/legal (e.g., right to own property; freedom of speech; liberty of the person, and the right to justice), political (e.g., right to vote and participate in the exercise of political power), and social (e.g., right to a certain level of economic welfare 
and security). To these rights, have been added cultural/symbolic rights that concern recognition, respect and protections with respect to identity (gender, race, sexuality, disability, faith, etc.). From this perspective, citizenship is "a set of practices (cultural, symbolic and economic) and a bundle of rights and duties (civil, political and social) that define an individual's membership in a polity (usually a nation-state)” (Isin \& Wood, 1999: 4).

In contrast, neoliberalism shifts citizenship away from inalienable rights and the common good towards a conception rooted in individual autonomy and freedom of 'choice', and personal responsibilities and obligations (e.g., Brown, 2016; Ong, 2006; Vanolo, 2016). Here, the onus is on the individual to navigate and negotiate the provision of services and levels of access, framed within 'commonsensical' constraints and neoliberal governmentality, based on their personal social, political and economic capital. As such, there is a reorientation of citizenship towards market principles and the market acting as a "means of regulating and coordinating the activities of numerous actors without direction from a single controlling centre” (Hindess, 2002, p. 140). As the work of city administrations is marketised, deregulated and privatised, the political and social aspects of citizenship likewise become transformed: instead of rights there are choices, with citizens framed increasingly as consumers able to select options on the basis of their ability to afford them. In the neoliberal smart city 'choice' is extended in space and time thanks to the proliferation of interconnected and location-aware devices.

This is having profound effects on governmentality. Smart technologies, in the form of networked sensors and real-time big data streams, establishes a neoliberal subject grounded in individual responsibility - for instance, by counting steps or measuring diets, analysing one's own data, and then recalibrating self-behaviour (see Davies, 2015). Han (2017, online) calls it "smartpolitics", arguing that the politics of discipline and punishment is being replaced by exploitation of the psychic realm: "instead of forbidding and depriving, [neoliberalism] works through pleasing and fulfilling”. This chimes with the notion that software is 'seductive' because it promises rewards for use, but at the same time it conditions through automation and forms of control (Kitchin \& Dodge, 2011). With the coupling of personal and environmental sensor data with the affordance of digital networking technologies, smartness can lead to a 'gamification effect' which constitutes notions of 'good' or 'bad' citizen/user through disciplinary dispositives of ordering or ranking (Vanolo, 
in press; see also Gabrys, 2014). According to Han (2017), the neoliberal subject is not a 'labourer' any more, but a 'project'. Even in smart city projects that seek more effective forms of active citizenship and citizen empowerment - e.g., Living Labs, citizen-science, open source software, sharing platforms - participation is achieved by co-opting citizen contributions into wider economic and neoliberal imperatives (Cardullo et al., 2018; McLaren \& Agyeman, 2015; Perng et al., 2018;).

The paradox of fostering increased choice with less meaningful participation for citizens is due to the contradictory coming together of forms of technocratic and marketdriven governance with poorly understood and practised notions of conviviality, commoning, civic deliberation, resource sharing, trust building, and other face-to-face forms of confrontation and living that make polis and communities work (Cardullo \& Kitchin, 2018b). While claiming to increase meaningful forms of direct participation, neoliberal governance works within structuring bureaucratic, technological and ideological path dependencies and representational practices that defines a citizenship regime (Cardullo \& Kitchin, 2018b; Joss et al., 2017), and often hinges on computational forms of participation which are set already within circumscribed software environments and solutions (Gabrys, 2014; Kitchin et al., 2017b). As Joss et al. (2017, p. 32) note, understanding the citizenship regime in operation within a smart city initiative needs to unpack: the "distribution of responsibility between the individual, the community, the market, and the state"; "the rights and obligations, which establish the boundaries of a political community"; and "the governing practices, including modes of citizen engagement and access to the state.” While this work has begun, including how postcolonial forms of citizenship are enacted in the Global South (Datta, 2018), there is much still to do across technologies, programmes and places.

\section{Social Justice and the Smart City}

Linked to the notion of citizenship, and the roles, rights and entitlements of citizens, is the notion of social justice and the expected and acceptable ways in which people are treated and the conditions in which they live. Social justice relates to the fair treatment of people in particular circumstances and how people should act (Smith, 1994). At a general level then, social justice concerns morality and human rights, where a right is an "obligation embedded in some social or institutional context where expectation has a moral force” (Smith, 1994, p. 36). In other words, moral rights are those things that we as members of a society expect as 
members, such as freedom of expression, access to accommodation, to vote in elections, full recourse to the law, access to education and medical treatment, etc. Such rights though are not given and inalienable, but are often highly contested, negotiated or imposed by members of a society. As Barry (1989) notes, theories of social justice are theories about the kind of social arrangements that can be defended. Indeed, there are a number of theories of social justice, with each theory appealing to a different forms of authority, logic and what matters most in life, and which justifies or challenges socio-spatial processes that discriminate against, marginalize and exclude some members of society (Harvey, 1996).

In general, theories of social justice fall into four broad types: distributional (fair share); procedural (fair treatment); retributive (fair punishment for wrongs); and restorative (righting of wrongs) (see Sabbagh \& Schmitt, 2016). Here, we want to consider the first two in relation to the smart city, though the effect on these can be shaped significantly by how punishments for wrong-doing are administered: in other words, if there is no effective sanction for social sorting and redlining within smart city initiatives, for example, then the moral argument with respect to distributional and procedural unfairness will have less traction. Importantly, which theory of social justice one subscribes to fundamentally alters how one understands fairness and rights and what one might consider to be a just smart city. Table 2 provides a snapshot of the main principles of seven theories and how they might apply in relation to some of the ethical issues of dataveillance, social/spatial sorting, anticipatory governance, dynamic pricing that differentially affect groups of citizens within the smart city (for a fuller discussion of social justice theories with respect to cities and urban geography, see Harvey, 1973, 1996; Heynen et al., 2018; Laws, 1994; Mitchell, 2003; Smith, 1994).

Table 2: Social justice and data-driven harms

\begin{tabular}{|l|l|}
\hline Theory of Social Justice & Application to data-driven harms \\
\hline $\begin{array}{l}\text { Egalitarianism argues for equality in terms of } \\
\text { distribution of wealth and power across all members } \\
\text { of a society regardless of ability and inheritance. }\end{array}$ & $\begin{array}{l}\text { Egalitarians would see data-driven harms and } \\
\text { differential treatment as an affront to their } \\
\text { principles of equality and demand that it be } \\
\text { removed or made equal in effects across all citizens. }\end{array}$ \\
\hline $\begin{array}{l}\text { Utilitarianism seeks the greater good for the } \\
\text { greatest number. }\end{array}$ & $\begin{array}{l}\text { Utilitarians would treat the problem as a social } \\
\text { nuisance that ought to addressed for the greater } \\
\text { good as it reproduces and deepens inequalities and } \\
\text { their long term effects; or that it should be tolerated } \\
\text { for greater good if benefits outweigh harms. }\end{array}$ \\
\hline
\end{tabular}




\begin{tabular}{|l|l|}
\hline $\begin{array}{l}\text { Libertarianism prioritises individual autonomy over } \\
\text { the state and society and suggests that the free- } \\
\text { market is inherently just. }\end{array}$ & $\begin{array}{l}\text { Libertarians would put the rights of data extractors } \\
\text { and profilers at a premium and what happens } \\
\text { between the parties involved is a private matter, } \\
\text { with citizens receiving the treatment they deserve or } \\
\text { can afford. }\end{array}$ \\
\hline $\begin{array}{l}\text { Contractarianism seeks to find a distributional } \\
\text { arrangement of resources that all involved considers }\end{array}$ & $\begin{array}{l}\text { Contractarians would look at the problem from all } \\
\text { sides, arguing that if one group is unwilling to } \\
\text { tolerate such data-driven harms then nobody should } \\
\text { and the systems should be dismantled. }\end{array}$ \\
\hline $\begin{array}{l}\text { Marxism argues that society has to be restructured } \\
\text { away from its current capitalist base into a society } \\
\text { where the full value of an individual's contribution is } \\
\text { rewarded. }\end{array}$ & $\begin{array}{l}\text { Marxists would argue that system that led to } \\
\text { surveillance capitalism needs to be changed to a } \\
\text { social democracy where people } \\
\text { discriminated, exploited and alienated. }\end{array}$ \\
\hline $\begin{array}{l}\text { Commot } \\
\text { determination and state sanctioned arrangements } \\
\text { and promotes the ideas of community and shared } \\
\text { practices and values. }\end{array}$ & $\begin{array}{l}\text { Communatarianists would suggest that within a } \\
\text { community system based upon shared experiences } \\
\text { and commonality such a system would not have } \\
\text { arisen and such principles need to be adopted. }\end{array}$ \\
\hline $\begin{array}{l}\text { Feminism argues for the redistribution of power, so } \\
\text { that power relations between different groups } \\
\text { becomes more just. }\end{array}$ & $\begin{array}{l}\text { Feminism would argue for end to practices of } \\
\text { discrimination and a redistribution of power } \\
\text { relations so that citizens have a much stronger say in } \\
\text { how such systems work and receive fair treatment. }\end{array}$ \\
\hline
\end{tabular}

Source: Reworked from Harvey's (1996) account of these theories with respect to a lead paint poisoning in rented accommodation.

What Table 2 highlights is that it is important to unpack the logics and principles as to how present smart cities are imagined and produced as 'just' or 'unjust' cities. As Don Mitchell (2003) notes, without such normative critique, the arguments used by smart city proponents will remain unchallenged in their claims to a common sense, pragmatic, nonideological approach to urban issues. Vanolo (in press) provides an example of such work using Harvey's theory of social justice to interrogate gamification and nudge in smart city systems. Equally, Table 2 makes clear that it is not simply enough to say one is interested in creating a 'just smart city', as if the meaning of such a statement is self-evident. Indeed, for a liberatarian, a neoliberal approach that prioritizes the free-market and individual autonomy and supports the notion of the survival-of-the-fittest rather than a welfare state, would argue that the neoliberal smart city and its attendant divides and inequalities are inherently just as one is treated as one deserves or can afford. Such a position is considered highly unjust by egalitarians, utilitarians, Marxists, and feminists. In other words, it is necessary for those seeking to create a normative argument for an alternative smart city vision to start to 
articulate the principles of a just smart city - perhaps organized with respect to conviviality, commoning, equality, civic deliberation, resource sharing and social reproduction - and how these would work in practice. This does not mean that one should halt seeking to attend to perceived injustices in the absence of such articulated principles, working in a pragmatic, instrumental and practical register (through activism and advocacy). Rather, it means that this should ideally be complemented with a nuanced, political, and normative argument that undermines the discourses and practices that support harmful and unjust outcomes and shifts the terrain of the debate in progressive ways. One way that such work has been advanced is through the political argument of the 'Right to the City', which has its roots in Lefebvre's Marxist-inspired ideas of social justice.

\section{The Right to the Smart City}

Henry Lefebvre (1996 [1967]) built his influential concept, 'The Right to the City', around the idea that citizens should not just have the right to occupy and use space, but that space should be shaped according to its inhabitants' needs (Purcell, 2002). For Isin (2000, p, 14) the right to the city is "the right to wrest the use of the city from the privileged new masters and democratise its space": it is the right of the excluded, the distressed and the alienated to demand and receive the material (e.g., a living wage, shelter) and non-material (e.g., recognition, respect, dignity) necessities of life (Marcuse, 2012). It is a demand that the rights of private property and the profit rate do not trump all other rights; that the current "right to the city, as it is now constituted ... restricted in most cases to a small political and economic elite who are in a position to shape cities more and more after their own desires” is radically reconfigured (Harvey, 2008, p. 38). As such, the 'right to the city' "consist[s] of the right of all city dwellers to fully enjoy urban life with all of its services and advantages - the right to habitation - as well as taking direct part in the management of cities - the right to participation” (Fernandes, 2007, p. 208).

This includes citizens possessing a suite of related rights, such as "the right to information, the right of expression, the right to culture, the right to identity in difference and in equality, the right to self-management, ... the right to public and non-public services” (Fernandes, 2007, p. 208), as well as the right to free movement, the right to occupy public spaces and to protect the commons from private ownership, the right to meetings and gathering, and the right to political representation and to vote. It is the right for inhabitants to 
participate fully in the production of urban space - "the right to control the urbanization process and to institute new modes of urbanization” (Harvey, 2008, p. 40) - not simply be the recipient of the practices of stewardship and civic paternalism enacted by city administrations and the market (Mitchell, 2003). In other words, the right to the city is "a moral claim, founded on fundamental principles of justice” (Marcuse, 2012), and it is a direct challenge to the inequities and injustices of urban capitalism and neoliberalism.

More recent extensions to the idea, important in the context of the smart city and its reliance on digital, networked technologies and the production and analysis of big data, are the 'right to the digital city’ (de Lange \& de Waal, 2013), 'digital rights to the city’ (see Shaw \& Graham, 2017a), and the 'informational right to the city’ (Shaw \& Graham, 2017b). de Lange and de Waal (2013) are interested in the right to appropriation in the smart city and seek to advance an alternative form of ownership, one not grounded in contracts and proprietary rights but rather in a "sense of belonging to a collective place ... and [a] willingness to share a private resource with the collective in order to allow other citizens to act, without infringing on other people's right of ownership”. Here, key infrastructures and resources, such as municipal data, are corralled within a commons and citizens have the right to use smart technologies to help solve shared issues by 'networked publics' who convene around a shared matter of concern. Shaw and Graham (2017b) are concerned that in an age of big data and data-driven urbanism citizens have the right to understand what data are being generated about them and places, within a framework which guarantees transparency with respect to how these data are compiled into information and the uses to which they are put, and thus have the ability to challenge and reconfigure those uses. More broadly, Isin and Ruppert (2015) argue that, given the ubiquitous nature of digital technologies in everyday life, there is a need for digital citizens to possess a suite of digital rights. Indeed, as Attoh (2011) notes, the right to the city “constitutes not a singular right, but a set of rights”.

At the same time, Marcuse (2012, p. 34), makes it clear that the "right to the city is a unitary right, a single right that makes claim to a city in which all ... separate and individual rights ... are implanted. It is The right to the city, not rights to the city. It is a right to social justice, which includes but far exceeds the right to individual justice.” In this sense it is a common right, not an individual right, and exceeds individual liberty (Harvey, 2008). Marcuse (2012) notes an "analogous concept might be that of citizenship ... that provides all rights as a right to the single status of citizenship.” Indeed, the concept highlights the vital 
link between the emancipatory organization and operation of cities and more empowering forms of citizenship and social justice. As Marcuse (2012) details, achieving such a coupling requires a significant shift in the nature of social relations as " $[t]$ o gain rights for those that do not have them will involve eliminating some rights for those that do: the right to dispossess others, to exploit, to dominate, to suppress, to manipulate the conduct of others.” Indeed, as Mayer (2012, p. 35) argues, in Lefebvre's terms, the right to the city is "not about inclusion in a structurally unequal and exploitative system, but about democratizing cities and their decision making processes.”

As Don Mitchell (2003, p. 19) notes, this sense of democracy requires systemic change in the underlying political economy, so that, "the use-value that is the necessary bedrock of urban life would finally be wrenched free from its domination by exchangevalue.” In other words, pursuing the right to the city means creating cities that are not rooted in and driven-by capitalism. In is only on these terms, Harvey contends, that a "genuinely humanizing urbanism” can be enacted (1973, p. 314; see Kitchin, 2018). That said, many who seek a fairer society are not pursuing revolution, but rather a more equitable and inclusive set of social relations within the existing structural asymmetries of capitalism (Marcuse, 2012; Mayer, 2012). Nonetheless, the right to the city is a rallying cry for transformative political mobilization to create such a humanizing urbanism; a more emancipatory and empowering city.

But what would such a smart city look like in practice? How can a 'right to the smart city' be achieved? There are few examples of progressive smart cities, but Barcelona's recent reorientation of its smart city ambitions offers some pointers (also see Ribera-Fumaz, in press). Under a right-wing government, Barcelona was a blueprint for neoliberal smart urbanism, partnering with multinationals such as CISCO, and performing various smart city initiatives with aggressive self-promotion, as well as initiating the SCEWC to promote smart cities more globally (March \& Ribera-Fumaz, 2016). Since May 2015, however, there has been a new political and organisational approach to smart cities. This has included making smart city initiatives much more citizen-centric and participatory, adopting the concept of ‘technological sovereignty’ as a new form of citizenship, and appointing a new commissioner of Technology and Digital Innovation. Technological sovereignty is the notion that technology should be orientated to and serve local residents, and be owned as a commons, rather than applying a universal, market-orientated, proprietary technology (Galdon, 2017; 
Morozov \& Bria 2018). Here, there is a commitment to using open source technologies and to retaining ownership and control of its data infrastructure while guaranteeing access for its citizens (Galdon, 2017). A new set of experiments with open data, control of personal data, civic apps, and crowdsourced sensors are connecting citizens to technology without curtailing their rights and entitlements (Bria, 2017). Further, service provision (electricity and water) is being re-municipalised and there are experiments with universal basic income and forms of rent control. Barcelona has thus sought to re-politicize the smart city and to shift its creation and control away from private interests and the state toward citizens and communities, civic movements and social innovation. The city's attempt to re-envisage the smart city around technological sovereignty offers a different form of smart citizenship, one that seems much more grounded in the hopes and politics of the 'right to the city' agenda.

Beyond the Barcelona example, a number of other cities are considering or have implemented specific measures to address various concerns relating to the neoliberal smart city. Morozov and Bria (2018: 23) classify these into: "those offering an alternative regime for dealing with citizen-produced data; those promoting an alternative, more cooperative model of service provision ... which does not rely on or promote data extractivism by a handful of giant tech firms; those seeking to control the activities of platforms like Airbnb or Uber...; and those promoting and building alternative infrastructures to compete with Silicon Valley.” In addition, within many cities there are bottom-up, community-driven and activist initiatives that seek to enact a different kind of smart city. It is clear, nonetheless, that creating the right to the smart city will require a ground-swell of action by social and political movements to demand change, and to formulate and implement alternative configurations, deployments and uses of smart city technologies. As Morozov and Bria (2018) note, however, it is not a matter of deciding which strategy comes first, the 'technological sovereignty' or the right to inhabitation through, say, social housing and accessible services: both struggles are valid. Rather, this is a matter of understanding the limits and possibilities of each strategy and integrating one inside the others.

The role of critical urban studies in enacting the right to the smart city is to 'expose, propose, and politicize’ (Marcuse, 2007). As Marcuse (2012, p. 37) elaborates: “Expose in the sense of analyzing the roots of the problem and making clear and communicating that analysis to those that need it and can use it. Propose, in the sense of working with those affected to come up with actual proposals, programs, targets, strategies, to achieve the desired 
results. Politicize, in the sense of clarifying the political action implications of what was exposed and proposed and the reasoning behind them, and supporting organizing around the proposals by informing action.” This is an ambition to which we aspire: to expose, propose and politicize the smart city; to envisage an alternative smart city founded on the principles of the 'right to the city.' Our challenge to others is to help make such smart cities.

\section{Acknowledgements}

The research for this paper was funded by an ERC Advanced Investigator award, 'The Programmable City’ (ERC-2012-AdG 323636-SOFTCITY).

\section{References}

Althusser, L. (1971). Lenin and Philosophy and Other Essays. Trans. Brewster B. London: NLB.

Amoore, L. (2013). The Politics of Possibility: Risk and Security Beyond Probability. Durham, NC: Duke University Press.

Arnstein, S. R. (1969). A ladder of citizen participation. Journal of the American Institute of Planners, 35(4), 216-224.

Attoh, K.A. (2011). What kind of right is the right to the city? Progress in Human Geography, 35(5), 669-684.

Baracos, S., \& Nissenbaum, H. (2014). Big data's end run around anonymity and consent. In J. Lane, V. Stodden, S. Bender,H. Nissenbaum(/Eeds), Privacy, Big Data and the Public Good (pp. 44-75). Cambridge: Cambridge University Press.

Barry, B. (1989). Theories of Justice. Berkeley: University of California Press.

Batty, M. (1997). The computable city. International Planning Studies, 2(2), 155-173. Braun, B.P. (2014). A new urban dispositif? Governing life in an age of climate change. Environment and Planning D: Society and Space, 32(1), 49-64.

Brenner, N., Marcuse, P., \& Mayer, M. (2012). Cities for People, Not for Profit: Introduction. In N. Brenner, P. Marcuse, \& M. Mayer (Eds.), Cities for People, Not for Profit: Critical Urban Theory and the Right to the City (pp. 1-10). New York: Routledge. pp. 1-10.

Bria, F. (2017). Reclaiming Europe’s digital sovereignty. Available at: https://www.acast.com/ft-tech-tonic/reclaimingeuropesdigitalsovereignty (accessed 30 
October 2017).

Brown, W. (2016). Sacrificial citizenship: neoliberalism, human capital, and austerity politics. Constellations, 23(1), 3-14.

Cardullo, P., \& Kitchin, R. (2018a). Being a 'citizen' in the smart city: Up and down the scaffold of smart citizen participation in Dublin, Ireland. GeoJournal, online first, doi: 10.1007/s10708-018-9845-8.

Cardullo, P., \& Kitchin, R. (2018b). Smart urbanism and smart citizenship: The neoliberal logic of 'citizen-focused' smart cities in Europe. Environment and Planning C: Politics and Space, online first. doi: 10.1177/0263774X18806508

Cardullo, P., Kitchin, R., \& Di Feliciantonio, C. (2018). Living labs and vacancy in the neoliberal city. Cities, 73, 44-50.

Carvalho, L. (2012). Urban competiveness, U-city strategies and the development of technological niches in Songdo, South Korea. In M. Bulu (Ed.), City competitiveness and improving urban subsystems (pp. 197-216). Hershey: Information Science Reference.

Castells, M. (1977). The Urban Question. A Marxist Approach. London: Edward Arnold.

Castells, M. (1988). The Informational City: Information Technology, Economic Restructuring and the Urban-Regional Process. Oxford: Blackwell.

Castells, M. (1996). The Rise of the Network Society. Oxford: Blackwell.

Christophers, B. (2011). Revisiting the Urbanization of Capital. Annals of the Association of American Geographers, 101(6), 1347-1364.

Cowley, R., Joss, S., \& Dayot, Y. (2018). The smart city and its publics: insights from across six UK cities. Urban Research \& Practice, 11(1), 53-77.

Crawford, K., \& Schultz, J. (2014). Big Data and Due Process: Toward a Framework to Redress Predictive Privacy Harms. Boston College Law Review, 55(1), 93-128.

Cugurullo, F. (2013). How to Build a Sandcastle: An Analysis of the Genesis and Development of Masdar City. Journal of Urban Technology, 20(1), 23 - 37.

Datta, A. (2015). New urban utopias of postcolonial India: ‘Entrepreneurial urbanization’ in Dholera smart city, Gujarat. Dialogues in Human Geography, 5(1), 3-22.

Datta, A. (2018). The Digital Turn in Postcolonial Urbanism: Smart citizenship in the making of India's 100 smart cities. Transactions of the Institute of British Geographers, online first https://doi.org/10.1111/tran.12225.

Davies, W. (2015). The chronic social: relations of control within and without neoliberalism. 
New Formations, 84/85, 40-57.

De Angelis, M. (2007). The Beginning of History: Value Struggles and Global Capital. London: Pluto.

de Lange, M., \& de Waal, M. (2013). Owning the city: New media and citizen engagement in urban design. First Monday, 18(11), available at: http://firstmonday.org/ojs/index.php/fm/article/view/4954 (accessed 1 February 2017)

Di Feliciantonio, C. (in press) Against the romance of the smart community: The case of Milano 4 You. In Cardullo, P., di Feliciantonio, C. and Kitchin, R. (eds) The Right to the Smart City. Bingley: Emerald Publishing.

Dutton, W.H., Blumler, J.G., \& Kraemer, K.L. (1987). Wired Cities: Shaping Future Communication. New York: Macmillan.

European Commission (2016) Horizon 2020 Work Programme 2016-2017. Cross-cutting activities (Focus Areas) No. 17. https://ec.europa.eu/research/participants/data/ref/h2020/wp/2016_2017/main/h2020wp1617-focus_en.pdf (last accessed 10 Oct 2018).

Evans, J., Karvonen, A. \& Raven, R. (Eds) (2016). The Experimental City. London: Routledge.

Fernandes, E. (2007). Constructing the right to the city in Brazil. Social and Legal Studies, 16(2), 201-219.

Flood, J. (2011). The Fires: How a Computer Formula, Big Ideas, and the Best of Intentions Burned Down New York City and Determined the Future of Cities. New York: Riverhead. Forrester, J.W. (1969). Urban Dynamics. Cambridge: MIT Press.

Foucault, M. (1991). Governmentality. In G. Burchell, C. Gordon, \& P. Miller. (Eds.), The Foucault Effect: Studies in Governmentality (pp. 87-104). Chicago, IL: University of Chicago Press.

Gabrys, J. (2014). Programming environments: environmentality and citizen sensing in the smart city. Environment and Planning D: Society and Space, 32(1), 30-48.

Galdon, G. (2017). Technological Sovereignty? Democracy, Data and Governance in the Digital Era. CCCB Lab, available at: http://lab.cccb.org/en/technological-sovereigntydemocracy-data-and-governance-in-the-digital-era/ (accessed 6th April 2018)

Goodman, M. (2015). Future Crimes: A Journey to the Dark Side of Technology - and How to Survive It. New York: Bantam Press. 
Graham, S. (2005). Software-sorted geographies. Progress in Human Geography, 29(5), 562580.

Graham, S., \& Marvin, S. (1999). Planning cybercities: Integrating telecommunications into urban planning. Town Planning Review, 70(1), 89-114.

Graham, S., \& Marvin, S. (2001). Splintering Urbanism: Networked Infrastructures, Technological Mobilities and the Urban Condition. London: Routledge.

Greenfield, A. (2013). Against the Smart City. New York: Do Publications.

Halpern, O., LeCavalier, J., Calvillo, N.,\& Pietsch, W. (2014). Test-bed urbanism. Public Culture, 25(2), 273-306.

Han, B.-C. (2017). Psychopolitics: Neoliberalism and New Technologies of Power. Brooklyn: Verso Books.

Hanley, R. (Ed.) (2004). Moving People, Goods, and Information in the 21st Century: The Cutting-Edge Infrastructures of Networked Cities. London: Routledge.

Harcourt, B.E. (2006). Against Prediction: Profiling, Policing and Punishing in an Actuarial Age. Chicago: Chicago University Press.

Harvey, D. (1973). Social Justice and the City. Oxford: Blackwell.

Harvey, D. (1996). Justice, Nature and the Geography of Difference. Oxford: Blackwell.

Harvey, D. (2008). The right to the city. New Left Review, 53, 23-40

Heynen, N., Aiello, D., Keegan, C., \& Luke, N. (2018). The Enduring Struggle for Social Justice and the City. Annals of the American Association of Geographers, 108(2), 301316.

Hill, D. (2013). On the smart city: Or, a 'manifesto' for smart citizens instead. City of Sound, 1 February. Available online: www.cityofsound.com/blog/2013/02/on-the-smart-city-acallfor-smart-citizens-instead.html (last accessed 5 February 2013).

Hindess, B. (2002.) Neo-liberal citizenship. Citizenship Studies, 6(2), 127-143.

Hollands, R.G. (2008). Will the real smart city please stand up? Intelligent, progressive or entrepreneurial? City, 12(3), 303-320.

Ishida, T.,\& Isbister, K. (2000). Digital Cities: Technologies, Experiences, and Future Perspectives. Berlin: Springer.

Isin, E.F. (2000). Introduction. In E.F. Isin (Ed.), Democracy, Citizenship and the Global City (pp. 1-21). London: Routledge.

Isin, E.F., \& Ruppert, E. (2015). Being Digital Citizens. London: Rowman \& Littlefield. 
Isin, E.F., \& Wood, P.K. (1999). Citizenship and Identity. London: Sage.

Jefferson, B.J. (2018). Predictable policing: Predictive crime mapping and geographies of policing and race. Annals of the American Association of Geographers, 108(1), 1-16.

Joss, S., Cook, M., \& Dayot, Y. (2017). Smart Cities: Towards a New Citizenship Regime? A Discourse Analysis of the British Smart City Standard. Journal of Urban Technology, 24(4), 29-49.

Karvonen, A., Cugurullo, F., \& Caprotti, F. (Eds). (2018). Inside Smart Cities: Place, Politics and Urban Innovation. London: Routledge.

Kitchin, R. (2014). The real-time city? Big data and smart urbanism. GeoJournal, 79(1), 114.

Kitchin, R. (2015). Making sense of smart cities: addressing present shortcomings. Cambridge Journal of Regions, Economy and Society, 8(1), 131-136.

Kitchin, R. (2016). Getting smarter about smart cities: Improving data privacy and data security. Data Protection Unit, Department of the Taoiseach, Dublin, Ireland. http://www.taoiseach.gov.ie/eng/Publications/Publications_2016/Smart_Cities_Report_Ja nuary_2016.pdf

Kitchin, R. (2018) Towards a genuinely humanizing smart urbanism. Programmable City Working Paper 42, https://osf.io/preprints/socarxiv/5jkx4

Kitchin, R. (2019). Reframing, reimagining and remaking smart cities. In C. Coletta, L. Evans, L. Heaphy, \& R. Kitchin (Eds.), Creating Smart Cities (pp. 219-230). London: Routledge.

Kitchin, R., Coletta, C., Evans, L., Heaphy, L., \& Mac Donncha, D. (2017a). Smart cities, urban technocrats, epistemic communities, advocacy coalitions and the 'last mile' problem. it - Information Technology, 59(6), 275-284.

Kitchin, R., Coletta, C., \& McArdle, G. (2017b). Urban informatics, governmentality and the logics of urban control. Programmable City Working Paper 25. Available at: https://osf.io/preprints/socarxiv/27hz8/.

Kitchin, R., \& Dodge, M. (2011). Code/Space: Software and Everyday Life. Cambridge, MA: MIT Press.

Komninos, N. (2002). Intelligent Cities: Innovation, Knowledge Systems and Digital Spaces. London: Routledge.

Laws, G. (1994). Social justice and urban politics: An introduction. Urban Geography, 15(7), 603-611. 
Lefebvre, H. (1996). Writings on Cities. Cambridge: Blackwell.

Leszczynski, A. (2017). Geoprivacy. In R. Kitchin, T. Lauriault, \& M. Wilson (Eds.),

Understanding Spatial Media. London: Sage.

Leszczynski, A., \& Kitchin, R. (in press). The seduction of UberCity. In M. Graham, R. Kitchin, S. Mattern, \& J. Shaw (Eds). Cities Should Be Run Like Companies and Other Fables. Oxford: Meatspace Press.

Light, J.S. (2004). From Warfare to Welfare: Defense Intellectuals and the Urban Problems in Cold War America. Baltimore: John Hopkins University Press.

Lyon, D. (1994). The Electronic Eye: The Rise of the Surveillance Society. Oxford: Polity Press.

March, H., \& Ribera-Fumaz, R. (2016). Smart contradictions: The politics of making Barcelona a self-sufficient city. European Urban and Regional Studies, 23(4), 816-830.

Marcuse, P. (2007). Social justice in New Orleans: planning after Katrina. Progressive Planning, Summer, 8-12.

Marcuse, P. (2012). Whose right(s) to what city. In N. Brenner, P. Marcuse, \& M. Mayer (Eds.), Cities for people not for profit: Critical urban theory and the right to the city (pp. 24-41). London: Routledge.

Marshall, T.H. (1950). Citizenship and Social Class. Cambridge: Cambridge University Press.

Massey, D. (2007). World City. Cambridge: Polity.

Mattern, S. (2013). Methodolatry and the art of measure: The new wave of urban data science. Design Observer: Places, 5 November, available at: http://designobserver.com/places/feature/0/38174/ (last accessed 15 November 2013).

Mattern, S. (2017). Code and Clay, Data and Dirt: Five Thousand Years of Urban Media. Minneapolis: University of Minnesota Press.

Mayer, M. (2012). The "right to the city" in urban social movements. In N. Brenner, P. Marcuse, \& M. Mayer (Eds..), Cities for people not for profit: Critical urban theory and the right to the city (pp. 63-85).. London: Routledge.

McLaren, D., \& Agyeman, J. (2015). Sharing Cities: A Case for Truly Smart and Sustainable Cities. Cambridge: MIT Press.

Mitchell, D. (2003). The Right to the City: Social Justice and the Fight for Public Space. New York: Guilford Press. 
Mitchell, W.J. (1995). City of Bits: Space, Place and the Infobahn. Cambridge: MIT Press. Moreno, L. (2014). The urban process under financialised capitalism. City, 18(3), 244-268. Morozov, E., \& Bria, F. (2018). Rethinking Smart Cities: Democratizing Urban Technology. New York: Rosa Luxemberg Stiftung. http://www.rosalux-nyc.org/rethinking-the-smartcity/

Ong, A. (2006). Mutations in citizenship. Theory, Culture \& Society, 23(2-3), 499-505.

Paasche, T.F. (2013). Coded police territories: 'detective software' investigates. Area, 45, 314-320.

Perng, S.-Y., Kitchin, R., \& MacDonncha, D. (2018). Hackathons, entrepreneurship and the making of smart cities. Geoforum, online first. doi: 10.1016/j.geoforum.2018.08.024

Purcell, M. (2002). Excavating Lefebvre: The right to the city and its urban politics of the inhabitant. GeoJournal, 58(2), 99-108.

Ramirez, E. (2013). The privacy challenges of big data: A view from the lifeguard's chair. Technology Policy Institute Aspen Forum, 19 Aug, available at: http://ftc.gov/speeches/ramirez/130819bigdataaspen.pdf (last accessed 11 Oct 2013).

Ribera-Fumaz, R. (in press) Moving from smart citizens to technological sovereignty? In Cardullo, P., di Feliciantonio, C. and Kitchin, R. (eds) The Right to the Smart City. Bingley: Emerald Publishing.

Robinson, J. (2005). Ordinary Cities. London: Routledge.

Sabbagh, C., \& Schmitt, M. (Eds.) (2016). Handbook of Social Justice Theory and Research. New York: Springer.

Sartori, L. (2015). Alla ricerca della “'smart citizenship”'. Istituzioni Del Federalismo: Rivista Di Studi Giuridici e Politici, 4, 927-948.

Sassen, S. (1991). The Global City: Princeton: Princeton University Press.

Shaw, J., \& Graham, M. (Eds.) (2017a). Our Digital Rights to the City. Oxford: Meatspace Press.

Shaw, J., \& Graham, M. (2017b). An informational right to the city? Code, content, control and the urbsanization of information. Antipode, 49(4), 907-927.

Shelton, T., \& Lodato, T. (in press). Actually existing smart citizens: Expertise and (non)participation in the making of the smart city. City.

Shelton, T., Zook, M., \& Wiig, A. (2015). The ‘actually existing smart city’. Cambridge Journal of Regions, Economy and Society, 8, 13-25. 
Shepard, M. (2011). Sentient City: Ubiquitous Computing, Architecture, and the Future of Urban Space. Cambridge: MIT Press.

Shin, H., Park, S.H., \& Sonn, J.W. (2015). The emergence of a multiscalar growth regime and scalar tension: the politics of urban development in Songdo New City, South Korea. Environment and Planning C, 33(6), 1618-1638.

Shwayri, S.T. (2013). A Model Korean Ubiquitous Eco-City? The Politics of Making Songdo. Journal of Urban Technology, 20(1), 39-55.

Smith, D.M. (1994). Geography and Social Justice. Oxford: Blackwell.

Söderström, O., Paasche, T., \& Klauser, F. (2014), Smart cities as corporate storytelling. City, 18(3), 307-320.

Taylor, L., Richter, C., Jameson, S., \& Perez del Pulgar, C. (2016). Customers, users or citizens? Inclusion, spatial data and governance in the smart city. Amsterdam: University of Amsterdam, available at: https://pure.uvt.nl/portal/files/12342457/Customers_users_or_citizens_Taylor_Richter_Ja meson_Perez_de_Pulgar_2016.pdf (last accessed 16 August 2016).

Taylor-Buck, N., \& While, A. (2017). Competitive urbanism and the limits to smart city innovation: The UK Future Cities initiative. Urban Studies, 54(2), 501-519.

Townsend, A. (2013). Smart Cities: Big data, Civic Hackers, and the Quest for a New Utopia. New York: W.W. Norton \& Co.

Vanolo, A. (2014). Smartmentality: The smart city as disciplinary strategy. Urban Studies, 51(5), 883-898.

Vanolo, A. (2016). Is there anybody out there? The place and role of citizens in tomorrow's smart cities. Futures, 82, 26-36.

Vanolo, A. (in press) Playable urban citizenship: Social justice and the gamification of civic life. In Cardullo, P., di Feliciantonio, C. and Kitchin, R. (eds) The Right to the Smart City. Bingley: Emerald Publishing.

Wiig, A. (2017,). Secure the city, revitalize the zone: Smart urbanization in Camden, New Jersey. Environment and Planning C: Politics and Space, online first,: doi: $10.1177 / 2399654417743767$.

Willis, K.,\& Aurigi, A. (2017). Digital and Smart Cities. London: Routledge. 